served fluorescence increase produced by this compound. An augmentation of the glycolysis and consequent accumbiation of lactate within the cytoplasira could be the cause of the debasement.

Thus, it is now clear that catecholamines produce both an improvement and a debasement of the myocardial redox state by directly affecting the myocardial energy metabolism. We are now studying the intracellular localization of the increased fluorescence and the biochemical events which underlie both the improvenent and the debasement of the myocardial redox state.

\title{
REFERENCES
}

1) Ribfitima, J., Wendt, V.E., Ramos, H., Gudbiarnason, S., Bruce, T.A. and Bing, R.J.: Am. Heart J. 67, 672 (1964); 2) Williamson, J.R. aNd Jamifson, D.: Mol. Pharmacol. 2, 191 (1966); 3) Imai, S., Ororir, T., Takeda, K. and Katano, Y.: Japan. J. Pharmacol. 25, 423 (1975): 4) Chance, B. and Legallais, V.: IEE Bio-med. Electron 10, 40 (196.3): 5) Kobayashi, S., Nishiki, K., Kaede, K. and Ogata, E.: J. Appl. Physiol. 31, 93 (1971); 6) Chancl. B., Williamson, J.R., Jamieson, D. and Scholner, B.: Biochem. Z. 341, 357 (1965); 7) WilLIAMSON, J.R.: J. biol. Chem. 240, 2308 (1965)

\section{NONSPECIFIC INHIBITORY ACTION OF CHINOFORM ON GASTROINTESTINE}

\author{
Issci TAKAYANAGI, Kazuichi HAYAKAWA*, Yasufumi TERAWAKI. \\ Zenzo TAMLRA* and Keijiro TAKAGI \\ Department of Chemical Pharmacology and *Department of Analytical \\ Chemistry. Faculty of Pharmaceutical Sciences, \\ University of Tokyo, Bunkyo-ku, Tokyo 113, Japan \\ Accepted May 17, 1976
}

The eflectiveness of chinoform (5-chloro-7-iodo-8-quinolinol) in the treatment of amocbic dysentry has been established $(1,2)$, however, recently it was concluded that SMON (Subacute Myelo-Optico-Neurophathy) is concerned with untoward side effects of chinoform (3). As gastrointestinal pharmacology of chinoform remains obscure, the present study was an attempt to determine the mode of action of chinoform on the gastrointestine.

Male guinea pigs ( 350 to $450 \mathrm{~g}$ in body $w 1$.) were sacrificed by a blow on the neck and the ileum was isolated. A picce ( 3 to $4 \mathrm{~cm}$ ) of the ileum was suspended in a $30 \mathrm{ml}$ organ bath filled with Locke Ringer solution, kept at $32^{\circ} \mathrm{C}$ and bubbled with air. Responses of the ileum to drugs were recorded through an isotonic lever. In most experiments, chinoform was applied to the serosal surface by addition to the bath fluid. In some experiments chinoform was applied to the mucosal surface, that is, into the lumen of the intcstinal segment, by passing a vinyl tube, the tip of which was within the intestinal sac (4). In other experiments the longitudinal muscle with Auerbach's plexus was carefully removed from a segment of the guinea pig ileum and was slipped onto a rectangular Lucite holder. The holder was 
mounted in oxygenated Locke Ringer solution at $34 \pm 0.5^{\circ} \mathrm{C}$ in a $10 \mathrm{~m} 1$ organ bath. A glass-suction electrode with tip diameters of 50 to $100 \mu$ and a resistance of less than 100 kiloohms, was set up so that the electrode directly touched Auerbach's plexus and electrical activities could be recorded according to the methods described in our previous report (5). Tension change of the smooth muscle was simultaneously recorded by using a mechanoelectical transducer (RCA5734).

The effect of chinoform on spontaneous movement of stomach was tested on rabbits. After a male rabbit $(2.5$ to $3.5 \mathrm{~kg}$ in body wt.) was laparotomized under sodium pentobarbitone ( $35 \mathrm{mg} / \mathrm{kg}$, i.v.) anaesthesia, a rubber microballoon was implanted into the muscle layer of the pyloric antrum (6). A fine vinyl tube for intraduodenal application of chinoform was also set within the duodenum through the muscle layer of the pyloric antrum. At least three days after the implantation and a fast of $24 \mathrm{hr}$, the experiments were begun in the unaesthetized rabbits. The internal pressure of the balloon was adjusted to $5 \mathrm{~cm} \mathrm{H}_{2} \mathrm{O}$ during smooth muscle relaxation. Changes in the internal pressure of the balloon were recorded by a low pressure transducer. About $2 \mathrm{ml}$ of blood was collected from A. auricular posterior every $30 \mathrm{~min}$ after the intraduodenal application of chinoform and the serum levels of chinoform were estimated by the nucthods of Chen et al. (7).

Chinoform was suspended in $0.8 \% \mathrm{CMC}$-Locke Ringer solution or $0.8 \% \mathrm{CMC}$-saline solution with a homogenizer. The Locke Ringer solution contained $9.0 \mathrm{~g}$ of $\mathrm{NaCl}, 0.4 \mathrm{~g}$ of $\mathrm{KCl}, 0.2 \mathrm{~g}$ of $\mathrm{CaCl}_{2}, 0.2 \mathrm{~g}$ of $\mathrm{MgCl}_{2}, 0.5 \mathrm{~g}$ of $\mathrm{NaHCO}_{3}$ and $0.5 \mathrm{~g}$ of glucose in one litre.

Acetylcholine was used as at smooth muscle stimulant and 5-hydroxytryptamine and nicotine as ganglion stimulants. Concentration action curves of acetylcholine, 5-hydroxytryptamine and nicotine were noncompetitively depressed by a 10 min treatment of the isolated ileum with chinoform $\left(10^{-3} \mathrm{~g} / \mathrm{m} 1\right)$. Maximum responses to all drugs decreased by 50 to $70 \%$. Responses to the drugs were unaffected by the 10 min treatment with $0.8 \%$ CMC. The present results coincide with the findings of Ohtsuka and Takahashi (personal communication) who found that chinoform inhibited spontaneous movement of the rabbit isolated jejunum and contraction of the guinea pig isolated ileum induced by acetylcholine. However, the responses of the isolated guinea pig ileum to acetylcholine $\left(10^{-8}\right.$ to $\left.10^{-6} \mathrm{~g} / \mathrm{ml}\right)$ were unaffected by $3 \mathrm{hr}$ application of chinoform $\left(4 \times 10^{-2} \mathrm{~g} / \mathrm{ml}\right)$ in the lumen.

After confirming that electrical activity of Auerbach's plexus and mechanical activity of smooth muscle were not affected by $0.8 \% \mathrm{CMC}$, chinoform $\left(10^{-3} \mathrm{~g} / \mathrm{ml}\right)$ was applied to the preparation. Chinoform $\left(10^{-3} \mathrm{~g} / \mathrm{ml}\right)$ inhibited the mechanical activity of the smooth muscle with no apparent change in the electrical activity of Auerbach's plexus while in the same preparation, tetrodotoxin $\left(10^{-7} \mathrm{~g} / \mathrm{ml}\right)$ did inhibit the electrical and mechanical activities (Fig. 1). This inhibition of the mechanical activity is due to inhibition of the electrical activity by tetrodotoxin. The present results clearly indicate that the site of action of chinoform is not on the cholinergic ganglion but on the smooth muscle and that chinoform has a nonspecific antispasmodic action.

Spontaneous movement of the stomach of the unanaesthetized rabbit was unaffected by $0.8 \%$ saline-solution (Fig. $2 \mathrm{~A}$ ). Effects of chinoform on spontaneous movement of the 


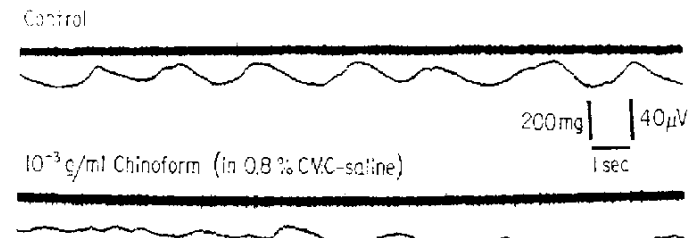

30 min cfter $10^{-3} \mathrm{~g} /$ mal Chirotort (in C.8\% CMC-saline)

$10^{-7}$ y/ril Tetrototoxi

Fig. 1. Effects of chinoform and tetrodotoxin on the electrical activity of Auerbach's plexus and mechanical activity of the smooth muscle.

upper trace : electrical activity, Lower trace : mechanical activity. $0.8 \% \mathrm{CMC}$ saline : $0.8 \% \mathrm{CMC}$-saline solution.
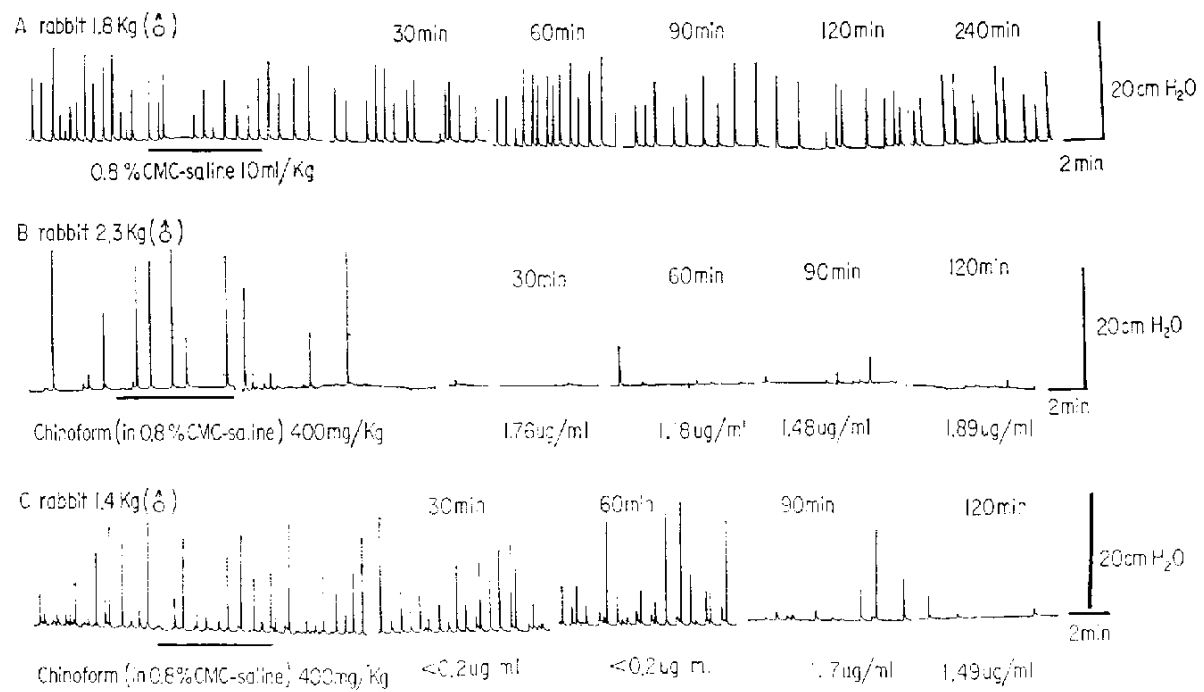

FIG. 2. Enects of chinoform on spontaneous movement of the stomach of the unanaesthetized rabbit. Chinoform suspension, in a volume was $10 \mathrm{ml} / \mathrm{kg}$, was applied intraduodenally. time ( $\mathrm{min}$ ): after the application of chinoform. Concentration $(\mu \mathrm{g} / \mathrm{ml})$ indicated at bottom : the amount of chinoform in serum.

stomach after the intraduodenal application of chinoform $(400 \mathrm{mg} / \mathrm{kg})$ were classified as follows.

Type 1. The inhibitory action was rapid in onset (Fig. 2B), as seen in four out of eleven experiments.

Type 2. Spontaneous movement of the stomach was inhibited after the latency period of 60 to 80 min (Fig. 2C) and four out of eleven experiments belonged to this type.

Type 3. No inhibitory response to chinoform was observed (data not shown) in three out 
of eleven experiments.

The level (mean \pm S.E.) of chinoform in serum was $1.50 \div 0.12 \mu \mathrm{g} / \mathrm{ml}$ when spontaneous movement was inhibited, and less than $0.32 \mu \mathrm{g} / \mathrm{ml}$ when no inhibitory action was observed. These results suggest that the inhibitory action of chinoform is due to the amount of chinoform absorbed and that variation of inhibitory activity in the rabbit stomach (Fig. 2) may be due to an individual difference in absorption from the intestine (unpublished observations). In the light of the present findings, the inhibitory action of chinoform is concerned with the blood level of chinoform absorbed.

\section{REFERENCES}

1) Anderson, H.H. and Koch, D.A.: Proc. Soc. exp. Biol. Med. 28, 828 (1931); 2) David, N.A., Johnstone, H.G., Beed, A.C. And Leake, C.D.: J. Am. Med. Ass. 100, 1658 (1933); 3) Kono, R.: Japan. J. med. Sci. Biol. 24, 195 (1971); 4) Pomeroy, A.R. AND Rand, M.R.: J. Pharm. Pharmacol. 21, 180 (1968); 5) Sato, T., TAKAyanagi, I. And TakaGl, K.: Japan. J. Pharmacol. 23, 665 (1973); 6) Nagasawa, K., Takayanagt, I., Miyamoto, M., Tomiyama, K. and Takagi, K.: J. Pharm. Pharmacol. 26, 665 (1973); 7) Chen, C.T., Samejima, K. And TAmura, Z.: Chem. Pharm. Bull. 24, 97 (1976). 